\section{"If You Want to Get Somewhere Else, You \\ Must Run at Least Twice as Fast as That!" \\ The Roots of the East Asian Crisis \\ Raphael Kaplinsky}

IDS Bulletin Vol 30 No 11999
'Nearly there!' the Queen repeated. 'Why, we passed it ten minutes ago! Faster!' And they ran on for a time in silence, with the wind whistling in Alice's ears, and almost blowing her hair off, she fancied.

'Now! Now!' cried the Queen. 'Faster! Faster!' And they went so fast that at last they seemed to skim through the air, hardly touching the ground with their feet, till suddenly, just as Alice was getting quite exhausted, they stopped, and she found herself sitting on the ground, breathless and giddy.

The Queen propped her up against a tree, and said kindly, 'You may rest a little now.'

Alice looked around her in great surprise. "Why, I do believe we have been under this tree the whole time! Everything's just as it was!'

'Of course it is' said the Queen. 'What would you have it?'

Well, in our country, said Alice, still panting a little, 'you'd generally get to somewhere else if you ran very fast for a long time, as we've been doing.'

'A slow sort of country!' said the Queen. 'Now, here, you see, it takes all the running you can do, to keep in the same place. If you want to get somewhere else, you must run at least twice as fast as that!'

(With due homage to the Red Queen)

* For the full version of this article, including the empirical material referred to, see Kaplinsky 1998b.

I am grateful to Marie-Jo Cortijo for her invaluable and excellent assistance with the collection and processing of data, and to comments from my colleagues Stephany Griffith-Jones, John Humphrey and Hans Singer and to participants at the East Asian Workshop. Adrian Wood has been a frequent and invaluable source of assistance and insight, not least in referring me to the wisdom of Lewis Carroll. The usual disclaimers apply.

1 This quote comes from Alice Through the LookingGlass (Carroll 1872: 145). 


\section{Introduction}

The East Asian crisis of 1997-98 is widely characterised as arising from unregulated and overambitious borrowing by private investors from private banking systems. Cronyism, poor banking regulation, and excessive and wildly optimistic borrowing by over ambitious corporations were seen to be the root causes of a growing recognition by the international finance community that many of these economies were characterised by a combination of high rates of indebtedness and poorly performing loan portfolios. This resulted in a crisis of confidence in the global banking community and an outflow of funds from the region. The ensuing currency depreciations magnified these systemic weaknesses, exaggerating the domestic-currency costs of external borrowings and increasing the likelihood of non-performing loans affecting the viability of both domestic and regional banking systems. What was initially a limited problem in a single economy (Thailand) rapidly spilled over into a regional crisis, with as yet unknowable global repercussions.

But, gradually, the explanation for this financial crisis has been revised and has become more nuanced. Although there were some unique features to this East Asian crisis, in other respects it replayed similar events in recent years, particularly the Mexican crisis of 1994. It is now widely recognised that this Mexican crisis, as well as similar events in other developing countries, arose at least in part from a tendency in global financial markets for short-term assets to both herd and to surge, into and out of recipient economies (Griffith-Jones 1996). The East Asian crisis is thus also partly to be explained in terms of the functioning of global financial markets, manifesting itself both in relation to excessively high inflows of funds into the region in the early 1990s, and then an overcorrection of capital flight after July 1997.

These contrasting approaches towards the global financial economy have led to a fierce policy debate, both in relation to the East Asian crisis itself and in the regulation of the global financial system. Four major strands can be identified. First, those commentators focussing on the determinants of demand for finance tend to stress the need for less regulation. They argue that greater transparency and fewer barriers to entry in both the banking system and in the productive economy will improve the process of financial intermediation and hence avoid the problems of the excessive and unrealistic demand for finance. This is a view largely associated with the policy prescriptions of the IMF and the global banking community, although it has a strong academic constituency in support. Second, there is a perspective which argues that whilst there may be a need to clean up the process of financial intermediation in these economies, the Fund handled the restructuring process ineptly, exaggerating the conditions which precipitated the outflow of short term capital surge from the region (Radelet and Sachs 1998). Third, others argue that far from a response of further deregulation, recent events in the region call for more, rather than less, regulation of banking systems and industrial investment. Here the argument is that there is a need to enhance banking regulation and to coordinate the demand for investment resources through sectoral industrial planning in order to avoid duplicating investments and excess capacity (Wade 1998; Chang forthcoming). Finally, observers focussing on the supply-side of the global financial equation, also tend to focus on the need for more rather than less regulation, both of domestic financial intermediation and borrowing, and of global capital flows (Griffith-Jones 1998). The imposition of a Tobin tax is often suggested as one way of curbing surges of highly mobile surges of capital in global financial markets (Haq et al. 1996).

Whichever way the argument is put, there seems to be some consensus that the primary - if not exclusive - cause of the East Asian crisis is to be found in the realms of finance, whether this be in regard to the efficiency and transparency of domestic financial intermediation or in the causes and nature of global financial flows. Even observers who adopt a market-regulating approach to the problem seem to concur with this perspective. Writing about Korea, Chang argues that the 'first thing to note about the current Korean crisis is that, contrary to the conventional wisdom [which argues that the Korean economy is overly regulated], it is largely [a] "financial" crisis in its origins, rather than a crisis in the "real economy" adding the reservation: 'although a severe financial crisis can easily turn into a crisis of the real economy' (Chang forthcoming: 1). 
The contribution of this article to the debate on the East Asian crisis in particular, and to repeated regional crises in general, is to address the link from the productive economy to the financial economy by focussing on medium- and long-run growth trajectories. The hypothesis will be explored that most of the East Asian economies locked themselves into a growth trajectory in which specialisation in factor and product markets associated with low barriers to entry led to high rates of competition. This has led to falling terms of trade and persistent currency realignments, placing long-run pressures on real exchange rates. During the 1980s this resulted in a process of competitive devaluations. But, against these longrun trends, in the early 1990s many of the regional economies experienced appreciating real exchange rates which led to growing problems in external markets. The 'currency appreciating bubble' was burst by the Chinese devaluation of mid-1994. The recent devaluations in the region exacerbated the crisis in the financial sphere and fed back into the productive sphere due to high gearing rates. They thus in part represent a reversion to long-run trends which reflected growth trajectories in the region. This being the case, the wider significance of the East Asian crisis is that competitive devaluations will be repeated there and elsewhere whenever outward-oriented growth strategies cluster in competitive activities. And the deeper the process of globalisation, the more likely these crises will be repeated in the future, and not just in East Asia.

This discussion should be seen not as an alternative and exclusive explanation of recent events in the region, but as providing supplementary insights. It is clear that the primary source of the immediate crisis lay in the financial sphere, both within the region and in the global financial system. But there has been a tendency to neglect the contribution of underlying growth trajectories to these problems in the region, in Mexico in 1994, and probably elsewhere in the future.

How is this hypothesis to be explored? In reality it is an issue involving complex inter-relationships between a number of variables, and sets out a new research agenda. In touching the boundaries of this research agenda, we will bring two sets of analysis to the table, illuminating long-term growth paths: the terms of trade and real exchange rates. ${ }^{2}$ In the concluding section we will briefly suggest other methodological frameworks which can be brought to bear in exploring underlying causes for crises such as that which we have recently witnessed in East Asia.

In the following section an analytical framework for understanding the East Asian crisis with a production focus (rather than through a financial lens) is laid out. In section 3 we briefly set out the scale and significance of Chinese entry into global markets in the 1980s. This plays an important role in the discussion which follows in section 4 , focussing on terms of trade and real exchange rates. The article concludes with some comments on the relationship between the recent East Asian crisis and of other crises that have beset (and may continue to beset) the global economy in the future, and a brief mention of other methodological frameworks that may be utilised to throw further light on the hypothesis under investigation.

\section{An Analytic Framework}

The primary hypothesis in this article is that most East Asian economies have been following growth trajectories which involve ever-intensifying competition in external product markets. In exploring this hypothesis, we will utilise the concepts of commodities and rent (elaborated in Kaplinsky 1998a). Let us begin with the definition of commodities. We define commodities as comprising factors and products in which there are few, or no, barriers to entry. Where barriers to entry are low, the resultant competition will tend to drive supply up, and prices and profits down. These market conditions can apply both to product markets (tea) or factor markets (unskilled labour). ${ }^{3}$ This analytical definition of commodities deviates from the more widely used characterisation of a group of primary products such as cocoa and copper. This product listing is only descriptive and is thus

\footnotetext{
2 The longer version of this article also includes a case study of the recent experience of the Korean semiconductor industry (Kaplinsky 1998b).
}

3 For a discussion of circumstances where unskilled labour can be classified as a commodity, see Kaplinsky (1993). 
unsatisfactory. It tells us little about the defining characteristics of the category of 'commodity'.

The second concept which throws light on our hypothesis is that of economic rent. Schumpeter argued that the function of entrepreneurship is to introduce 'new combinations' which would allow for the construction of barriers to entry, providing protection from these competitive pressures and an escape from commodity markets. ${ }^{4}$ He argued that these rents arise from - and indeed define - the act of innovation. Building on this edifice, neoSchumpeterians (and to some extent endogenous growth theorists) have tended to focus on the role played by technological progress in the creation of innovation rents. However, this focus on technological rents is too narrow, since there are a range of other sources of rent which provide the capacity to give protection from severe competition. These include policy rents, resource rent, organisational rents, relational rents, human resource rents, and marketing rents (Kaplinsky 1998a). The linkage between these two concepts - commodities and rent - is obvious and follows from the form and extent of barriers to entry in product and factor markets.

Three relevant and important issues arise from this discussion. First, the ability to appropriate rents is crucial for sustained income growth. Second, rents are dynamic. As the pace of globalisation speeds up, like the Red Queen and Alice, firms and economies constantly need to run faster just to stand still, fighting to raise productivity and product innovation faster than the decline in margins as competitive pressures intensify. What is scarce today - for example, the ability to fabricate semiconductor memory chips, or to assemble automobiles - will become common tomorrow. Thus the ability to sustain income growth depends upon the capability to respond flexibly to changing competitive circumstances. And, third, as Robert Reich and others have pointed out, the ability to physically transform inputs into outputs is increasingly widespread and

\footnotetext{
4 Schumpeter identified four major types of 'new combinations': the introduction of new machinery; 'replacing one product with another'; 'the creation of a new good which more adequately satisfies existing and previously satisfied needs'; and 'the search for new markets in which an article has not yet been made familiar and in which it is not produced'. (Schumpeter 1961: 134-5.)
}

in many sectors involves few barriers to entry (Reich 1991). Instead, rent increasingly accrues in design, in branding, in marketing and in value chain integration (Kaplinsky 1998a). In the context of a competitive environment these rents can only be appropriated through a strategy which sustains upgrading at a higher pace than competitor economies.

To simplify the argument there are two possible responses to growing competitive pressures. The 'high road' is to upgrade production in such a way as to capture rents, to create barriers to entry, and hence to escape the competitive pressures. The low road' is to lower prices as a way of maintaining or increasing market share. One major indicator of which competitive response is followed is the economy-wide terms of trade. If these decline, it can be argued that the 'low-road' of price competition was chosen; if they rise, it suggests that these economies have been able to move out of commodity segments of production and to compete on non-price qualities or to move into sectors which face less price competition.

A second macroeconomic indicator of competitive response is the real exchange rate (RER). The linkage between growth trajectories and the RER is as follows. The inability to appropriate rents via product improvements or process innovations, or by migrating to less competitive sectors, forces firms to reduce prices. To some extent this is under the control of the enterprise which can improve its own productivity, make its supply-chain more effective, and source from lower-cost suppliers. But there is only a limited space in which these firms can operate in lowering their costs, since they are critically affected by key macroeconomic variables, including the rate at which domestic currency converts into foreign currency. ${ }^{5}$ Hence, the exchange rate becomes an important macroeconomic weapon supporting (and indeed guiding) the competitive response at the level of the firm. A depreciating real exchange rate, by lowering the 'international' value

\footnotetext{
5 In fact the empirical literature shows that in addition to the level of the exchange rate, the ability of firms to survive and thrive in global markets depends significantly on the stability of the exchange rate (Helleiner 1994).
} 
of wages, both reinforces and reflects a strategy based upon price competitiveness rather than on the accretion of rents. ${ }^{6}$

The RER is an imperfect indicator of long-term growth trajectories. It is affected by a number of other variables including the relative size of the traded-goods sector of the economy, the economy's openness, and the existence of a single or limited number of rent-rich commodity exports (such as the role played by gold for many years in South Africa). Nevertheless, it does provide a revealing window into long-term growth trajectories.

Based on this analytical framework, we derive the hypothesis that the recent currency devaluations in the East Asian region in part reflect a crowding of many of these economies into commodity-type sectors, sub-sectors or activities in sectoral value chains. ${ }^{7}$ This has occurred over a number of decades, picking up pace during the 1980s and 1990 s as more and more of the regional economies developed the productive capacity to enter these markets. The growing depreciation of the Chinese exchange rate after 1980, and China's entry into global markets as an exporter of significance in 1985, not only led to a surge in its market share, but also to growing price competition and thus to a significant decline in all least developed countries (LDC) terms of trade in manufactures. In the very recent period, these pent-up competitive pressures spilled over into competitive devaluations, following the 'devaluation' of the Chinese yuan in January $1994{ }^{8}$ This is a similar process to that which occurred in Central America in the 1980s
(Kaplinsky 1993). There, a round of competitive devaluations, based in part on fallacy-of-composition policies pursued under structural adjustment programmes (SAPs) promoted by the multilateral agencies, resulted in a process of immiserising growth. Until recently this spectre of immiserising growth - an increase in economic activity which results in lower per capita incomes - has not been evidenced in the Asian region, but it is a spectre which haunts the region's future.

\section{The Regional Backdrop: The Entry of China into Global Markets}

As will become clear in the discussion which follows, an important factor contributing to the regional crisis has been the entry of China into global markets as a major exporter of manufactured products. From the early 1980s, the rate of depreciation of the Chinese RER speeded up (Figure 1)..$^{9}$ This was a prelude to China's entry into global export markets, a process which gathered pace as the decade wore on. This entry into global markets after 1985 represented a non-marginal shift in the global trading environment. For example, if we look at a series of product markets which reflect LDC comparative advantage, the pace and depth of this new market presence in the USA and Japan is astonishing. Within a very brief space of 15 years, China became the major source of imports in a number of commodities of significant trade importance in the Asian region (Table 1). Wood argues that the scale of this onslaught on global markets, buttressed by the low prices of Chinese products, resulted in a 20

\footnotetext{
- This is not a problem only facing developing economies. The former head of Volkswagen, addressing the Royal Society in the UK in 1993, posed the challenge to his audience that because of a low exchange rate, UK wages were too low to foster innovation - Let me put a provocative question: "Are wages too low to exert sufficient pressure for real progress?"' (Icahn 1993: 443).
}

\footnotetext{
The concept of the 'value chain' has a lineage stretching back to the early 1970s. It describes the full range of activities which are required to bring a product from its conception, through its design, its sourced raw materials and intermediate inputs, its marketing, its distribution and its support to the final consumer. In other words, the value chain can be seen as incorporating production, exchange, distribution and consumption from the cradle to grave of a given product or service.
}

\begin{abstract}
${ }^{8}$ There is some dispute concerning the extent of this 1994 devaluation. The change in the official rate from \$USO.17 to $\$ 0.12$ was less dramatic than it seems, since many enterprises had been trading at the unofficial black-market rate for some time. Some estimates are that less than 10 per cent of China's external trade was conducted at the official rate. However, although the unofficial rate of devaluation was much lower than the official rate, there were significant transaction costs in obtaining these (illegal) foreign currencies (I am grateful to Ray Bean Dawn for this observation). Moreover, whatever the reality, many of China's competitors perceived that the devaluation was indeed significant and responded as if this were the case.
\end{abstract}

9 For a description of the methodology utilised in the calculation of real exchange rates, see Kaplinsky $1998 \mathrm{~b}$. 
Figure 1: China: weighted RER index, 1976-85 (1985 = 100)

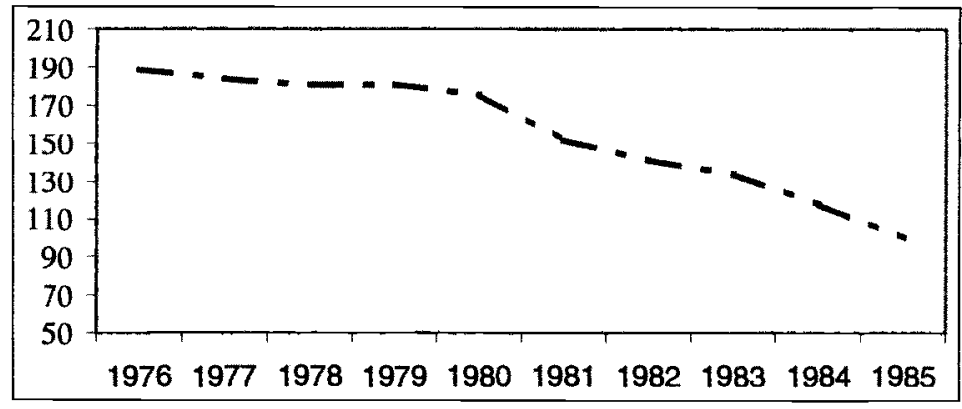

Source: http://www.ids.ac.uk/ids/research/kaplin.pdf

Table 1: Share of merchandise imports from China

\begin{tabular}{|c|c|c|c|c|c|}
\hline & \multicolumn{3}{|c|}{ USA } & \multicolumn{2}{|c|}{ Japan } \\
\hline & 1980 & 1990 & 1994 & 1990 & 1994 \\
\hline Textiles & 5.9 & 10.3 & 11.5 & 19.7 & 32.5 \\
\hline Clothing & 4.0 & 13.7 & 17.3 & 27.5 & 53.9 \\
\hline Other consumer products & 0.8 & 11.0 & 24.0 & 4.5 & 17.0 \\
\hline Footwear & 0.7 & 15.7 & 45.2 & 12.5 & 43.5 \\
\hline Toys and games & 0.1 & 25.0 & 48.7 & 7.7 & 25.0 \\
\hline Total merchandise imports & 0.5 & 3.1 & 6.0 & 5.1 & 10.1 \\
\hline
\end{tabular}

Source: WTO 1995

per cent decline in the terms of trade of LDC manufactured exports (Wood 1997). This is corroborated by a recent study of the barter terms of trade in manufactures between developing countries and the European Union, which estimates an annual rate of depreciation of 2.2 per cent between 1979 and 1994 (Maizels et al. 1998). This mirrors an earlier decline in their terms of trade in primary materials and agricultural products and, incidentally, reinforces the conclusion drawn above that commodities are defined by factor and product markets rather than by the nature of the goods being produced.

\section{Macro Evidence: Terms of Trade and Real Exchange Rates}

An analysis of the terms of trade of the major economies in the region (bar Taiwan and Singapore for whom comparative data are not available) suggests three competitive responses in the region over the 1960-1996 period (the data is presented in the full version of this article - see Kaplinsky 1998b):

- Economies which initially experienced declining terms of trade and which then subsequently experienced appreciating terms of trade. This is consistent with a long-term growth strategy which began with price-competition and then switched to innovation enabling the economy to appropriate various forms of rent. Japan is the solitary example of this in the Asian sample, 
Table 2: Comparison between terms of trade and RER performance, 1960-1997

\begin{tabular}{|c|c|c|c|}
\hline & \multirow[t]{2}{*}{ Terms of trade } & \multicolumn{2}{|c|}{ Real Exchange Rates } \\
\hline & & Weighted* & Against $\$ U S$ \\
\hline Rising & Japan & $\begin{array}{l}\text { Japan, Hong Kong, } \\
\text { Singapore }\end{array}$ & $\begin{array}{l}\text { Japan, Hong Kong, } \\
\text { Singapore, Taiwan }\end{array}$ \\
\hline $\begin{array}{l}\text { Rising and subsequently } \\
\text { falling }\end{array}$ & $\begin{array}{l}\text { China, Indonesia, Korea, } \\
\text { Malaysia, Philippines }\end{array}$ & Indonesia & Indonesia \\
\hline Falling & $\begin{array}{l}\text { India, Hong Kong, } \\
\text { Thailand }\end{array}$ & $\begin{array}{l}\text { China, India, Korea, } \\
\text { Malaysia }\end{array}$ & $\begin{array}{l}\text { China, India, Korea, } \\
\text { Malaysia }\end{array}$ \\
\hline Static & & Philippines, Thailand & Philippines, Thailand \\
\hline
\end{tabular}

* no consistent set of trade weights could be found for Taiwan for the full period under consideration

although it is probable that, were equivalent terms of trade data to be available, the same processes could be witnessed for Singapore and Taiwan (see the following discussion on real exchange rates).

- Economies which initially experienced rising terms of trade, but which, from the late 1970 s onwards, were forced into declining terms of trade as global competition (and the presence of China in global markets) increased and as they were unable to upgrade their production profiles. This includes China, Indonesia, Malaysia, the Philippines and, surprisingly, Korea. Some of these economies - especially Indonesia and Malaysia - gained from the appreciation of oil prices during the 1970s.

- Economies which consistently proved unable to meet competition without reducing prices. This group includes India, Thailand and Hong Kong. ${ }^{10}$

The second set of macroeconomic data which illuminates this article's hypothesis are the RERs. Two sets of RER have been calculated for the region. The first is the bilateral rate against the US dollar, using the US wholesale price index as a comparator. The second is the weighted rate, which as can be seen closely follows the bilateral rate. (The methodology utilised and the data are presented in Kaplinsky 1998b.) These two sets of real exchange rates show a similar pattern to those emerging from the analysis of terms of trade, namely a group of economies experiencing:

- Rising RERs: Japan, Hong Kong, Singapore and Taiwan (using bilateral rates with the US)

- Rising RERs which subsequently fell: Indonesia

- Falling RERs: China, India, Korea and Malaysia

- Static RERs: the Philippines and Thailand.

Table 2 compares these two sets of macroeconomic indicators of long-term growth paths. They broadly tell the same story, that is, that there are a group of economies following the 'high road' of rent accretion - Japan, Singapore and Taiwan - and those following a 'low road' of commoditising production and price competition. Korea stands somewhere in between these two classifications, an observation reinforced both by the case study on semiconductor memories (see Kaplinsky 1998b) and by a recent study by Maizels et al. (1998). The major anomaly between these two macroeconomic indicators of growth trajectories is that of Hong Kong, which experienced falling terms of trade, but an appreciating RER. It is also notable that despite falling terms of trade, both the Philippines and Thailand experienced relatively static RERs.

What light do these long-term trends in terms of trade and RERs throw on the regional crisis in 1997-98? Table 3 charts the RERs of these economies over four periods: the long term from

\footnotetext{
${ }^{10}$ Hong Kong is a surprising participant in this group, which is probably explained by two contrasting factors. First, particularly in recent years, much of Hong Kong's exports represent the re-export of low-value added goods from China. This would help to explain the fall in terms of trade. However, Hong Kong has also made a
}

significant transition into higher value-added services (which does not show up in the terms of trade data), which helps to explain why its RERs increased. (I am grateful to Helmut Reisen for pointing this latter factor out to me.) 
Table 3: Trends in weighted RERs

\begin{tabular}{lrrrr}
\hline & $1966-80$ & $1980-90$ & $1990-96$ & $1966-96$ \\
\hline China & -3.95 & -8.09 & -2.66 & -5.10 \\
Hong Kong & 2.81 & -0.56 & 7.11 & 2.51 \\
India & -1.54 & -3.88 & -4.98 & -3.02 \\
Indonesia & 4.48 & -4.17 & 1.49 & 0.23 \\
Japan & 1.72 & 0.61 & 1.00 & 1.21 \\
Korea & 0.52 & -1.06 & -1.71 & -0.45 \\
Malaysia & -0.78 & -1.61 & 2.81 & -0.35 \\
Philippines & -1.76 & 0.48 & 1.61 & 0.48 \\
Singapore & 0.25 & 1.45 & 3.25 & 1.36 \\
Taiwan & & 2.58 & -2.66 & -0.40 \\
Thailand & 0.55 & -1.12 & 1.55 & 0.19 \\
\hline
\end{tabular}

Indonesia $=1971$, not 1966

Singapore $=1969$, not 1966

Taiwan $=1985$, not 1980

Philippines $=1969$, not 1966

Source: Kaplinsky 1986

the early 1960s until 1997; the period before China's entry into global markets during the 1980s; the 1980s; and the 1990s. The story it tells is that:

- Over the long term, RERs have been declining in many of the regional economies

- During the 1980s, the rate of decline increased (or conversely, where relevant, the rate of appreciation reduced) as the regional economies were forced into price competition with China

- As the balance of payments improved in many of these economies during the export boom of the late 1980s, ${ }^{11}$ and as Foreign Direct Investment (FDI) inflows into the region increased, ${ }^{12}$ global sentiment changed in favour of these regional economies. The consequence was a large inflow of funds. These inflows were, as we know, generally from private lenders to private borrowers, facilitated by the liberalisation of the capital account in some economies (especially Korea) which allowed the private sector to borrow abroad directly, in foreign-currency denominated loans. In addition, the exchange rates of many of these economies were loosely pegged to the US dollar, which was rising. The consequence of all of these developments was a relative appreciation in RERs in a significant number of regional economies between 1990 and 1996 (Table 4). The lower domestic currency repayment costs of external loans resulting from currency appreciation merely reinforced these trends.

Then came the Chinese devaluation of July 1994, following the deteriorating balance of payments performance of many countries in the region resulting from the RER appreciation of the early 1990s. ${ }^{13}$ Even though the effective devaluation was much lower than the change in nominal rates (see footnote 8), it nevertheless played an important role in the subsequent devaluations by regional economies

\footnotetext{
"One of the primary results of these devaluations was the sustained balance-of-payments improvement with the deficit for the region as a whole averaging only 0.3 per cent of GDP p.a. between 1985 and 1989; Korea and Malaysia averaged surpluses of 4.3 per cent and 2.4 per cent of GDP (Radelet and Sachs 1998).

${ }^{12}$ For example, between 1991 and 1995, FDI rose from $\$ 3.5 b n$ to $\$ 33.9 b n$ (and to $\$ 38.1$ bn in 1996 ) into
}

\footnotetext{
China, from $\$ 74 \mathrm{~m}$ to $\$ 2 \mathrm{bn}$ into India, from $\$ 1.5 \mathrm{bn}$ to $\$ 3.8 \mathrm{~b}$ into Indonesia, and from $\$ 544 \mathrm{~m}$ to $\$ 1.1 \mathrm{bn}$ into the Philippines.

${ }^{13}$ Contrasting with the experience of the late 1980s (see previous footnote 11), the current account of the region averaged a deficit of 4 per cent of GDP between 1990 and 1996 (Radelet and Sachs 1998).
} 
Figure 2: Exchange rate depreciation, July 1997 onwards

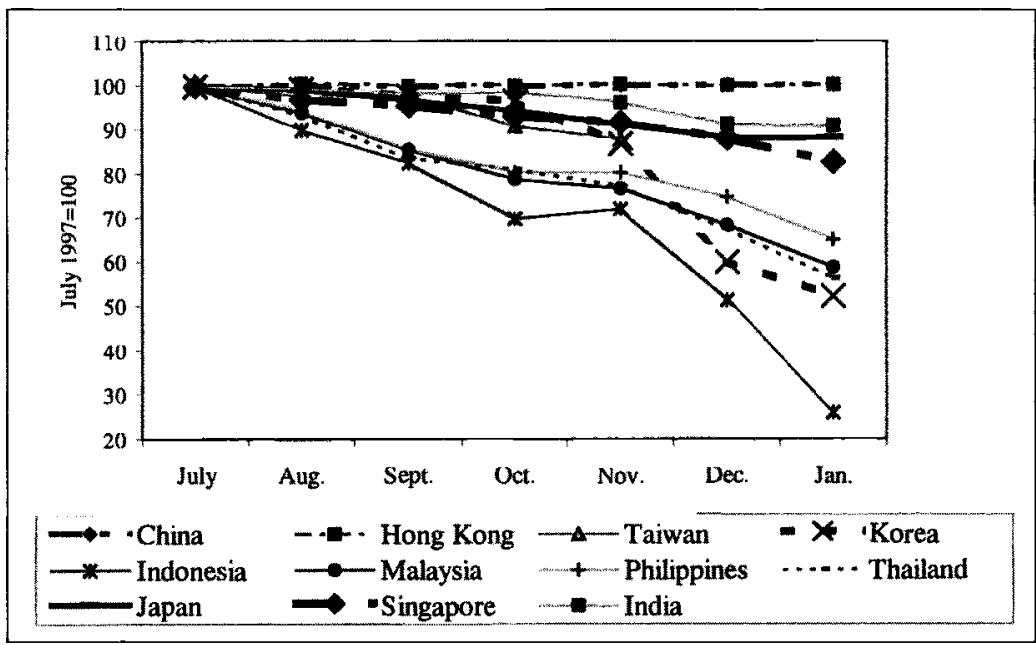

Source: http://www.ids.ac.uk/ids/research/kaplin.pdf

Table 4: (Weighted) RER index for seven regional economies, 1990-1996 $(1990=100)$

\begin{tabular}{ll}
\hline Country & $\begin{array}{l}1996 \text { RER index } \\
(1990=100)\end{array}$ \\
\hline Hong Kong & 150 \\
Indonesia & 109 \\
Japan & 106 \\
Malaysia & 118 \\
Philippines & 110 \\
Singapore & 121 \\
Thailand & 110 \\
\hline
\end{tabular}

(Figure 2). ${ }^{14}$ These in turn exacerbated the growing burden of domestic currency debt by firms which had borrowed in external currencies, bank defaults, and a tumbling into the crisis which now besets the region. The key thing from the perspective of this article is that, although representing a significant over-correction, in most cases these currency realignments reflected a reversion to long-run trends.

\section{Conclusions}

What conclusions can be drawn from this analysis of the development of terms of trade and RERs in East and South Asia during the post- 1960 period, and of the recent experience of the Korean semiconductor industry?

First, it provides a context for viewing the dramatic changes in exchange rates after mid-1997. As we have seen, although the immediate drivers for these currency changes are predominantly to be found in financial markets, there are underlying economic processes at work which suggest that these shortterm changes may in part have been a (too-) large adjustment in currency alignments, following logically from past growth trajectories. This affected not just the obvious candidate countries. Even in the case of Korea, the worsening balance of payments current account (from a surplus of $\$ 0.4 \mathrm{bn}$ in 1993 to a deficit of $\$ 4.5 \mathrm{bn}$ in $1994, \$ 8.9 \mathrm{bn}$ in 1995 and $\$ 23.7$ bn in 1996) was to a significant extent a function of Korea's export dependence on a single product (dynamic randome access memories (DRAMs)) which increasingly became commoditised during the 1990s. Thus, there is a danger that the
${ }^{14}$ Due to the difficulty in obtaining trade weights for the most recent period, these devaluations are calculated against the US dollar. 
consequences of growth trajectories based on the production of commodities may engulf regional economies other than the obvious cases of China, India, Indonesia, the Philippines and Thailand, let alone new aspirant commodity exporters such as Bangladesh, Pakistan and Vietnam. A trigger for this might be a renewed devaluation by China or Japan, seeking to make up lost competitive ground following devaluations in the region during 1997 and 1998. The East Asian crisis may not yet have worked itself through.

Second, our analysis of the productive factors underlying the East Asian crisis suggests a generic process at work. As competitive pressures increase, so there is a continual tendency for the commoditisation of product and factor markets. For every successful 'upgrading' - in a firm, a region or an economy - there is necessarily a relative 'downgrading' by others. When these 'downgradings' cluster, in a sector, an economy or in a group of economies, there is renewed potential for a similar crisis to that which has occurred in East Asia, in which developments in the real and financial economies feed into each other. The 1998 BIS Annual Report provides a corroborating judgement on this:

As noted in last year's Annual Report, indications of excessive investment in particular sectors had already emerged in 1996. In that year, the massive investment in Asia's electronics industry contributed to conditions of oversupply and a resulting price collapse in world markets. But investment has sharply increased in other areas as well (such as automobile construction, household appliances and electricity generation) at the risk of flooding local and foreign markets.

Overinvestment in particular sectors has tended to erode the rates of return on capital in recent years.

(BIS, 68th Annual Report, 1998: pp 35-6)
Third, this decline in RERs may or may not add up to immiserising growth, that is, increased economic activity resulting in lower standards of living through declining income terms of trade..$^{15}$ The likelihood of this phenomenon emerging depends upon the ability of these devaluing economies to sustain the growth of exports. In Central America it resulted in a significant decline in per capita incomes during the 1980s (Kaplinsky 1993; InterAmerican Development Bank 1990). A similar process can currently be observed for sub-Saharan Africa. So far, in the Asian region at least, export volume growth seems to have more than compensated for declining terms of trade. Thus, sustainable growth is a function of two variables, both of which are subject to change. The first is the rate of terms of trade decline. This increased during the 1980s for manufactures (Wood 1997 and Maizels et al. 1998) and given the post-crisis Asian devaluations, will probably increase at an even faster rate in the future. The second is the growth of world trade. A spilling over of the East Asian crisis into the global economy may either be deflationary or lead to growing protectionism. For example, in the first half of 1998, Chinese textile exports to Japan were down 50 per cent on the same period in 1997 (Observer, 14 June 1998). So the prospects of immiserising growth, even in Asia, cannot be ruled out. There remains scope for a Malthusian closure to globalisation in which the openness of economies drives real wages to the rate of subsistence in much of the global economy, particularly in those economies concentrating on the realisation of comparative advantage through specialisation in labour-intensive commodities. ${ }^{16} \mathrm{~A}$ race-to-the-bottom remains a realistic outcome to globalisation.

Fourth, we return to our original theme in which we suggested a hypothesis explaining the Asian crisis. Positing a link from the productive economy to the financial sphere of activity, we have suggested that these Asian economies increasingly became locked into commoditised sectors and sub-sectors of production, resulting from a process of

\footnotetext{
${ }^{15}$ It is important here to distinguish between barter-, income- and factorial-terms of trade. For a discussion of the circumstances in which declining terms of trade might add up to immiserising growth, see Kaplinsky $1998 \mathrm{a}$

16 Wood's 'bas-ed' labour force - with less than four
}

years of education - has indeed experienced falling real standards of living despite active participation in the real economy (Wood 1994). Between 1972 (the peak) and 1996 , average real wages in the US fell by 19 per cent and the average working week rose by 3 per cent (Kaplinsky 1998a). 
increasing price competition and competitive devaluations. The tools which we brought to bear to this argument were macroeconomic analyses of terms of trade and RERs (and a brief library-based review of part of the Korean semiconductor industry - see Kaplinsky 1998b). But these can at best only be regarded as preliminary analyses. More detailed, and preferably primary-research-based analyses need to be conducted to determine whether this preliminary analysis can be validated for the countries in question, what the effective sources of rent appropriation are and how these vary over time and between sectors, and to what extent these convulsions may apply to other economies. Moreover, it is also important to understand why some of the Latin American economies (such as Brazil) which have also recently experienced rising RERs despite long-term falling terms of trade and RERs (BIS 1998: 49), have not (so far?) experienced the same crisis conditions as the Asian region.
Finally, it is important to explore whether this crisis represents a one-off, or is a reflection of a deeprooted structural problem in the global economy, which will reassert itself elsewhere in the future. One possible structural factor may be that these repeated financial crises arise in part because of a systemic imbalance between financial and productive resources, exacerbated by the more rapid growth in the value of financial assets. This excessive liquidity finds expression in repeated surges of financial capital seeking a vent for surplus. Is it a mere coincidence, for example, that the P/E ratios in Western stock-markets are now higher than at any point since the Second World War? ${ }^{17}$ If these events are related, it throws the policy debate more problematically onto the determinants of various categories of asset growth (and particularly onto the market for financial derivatives of various sorts). But, clearly, research is needed on these issues before any informed judgements can be made. 


\section{References}

Balassa, B. (1982) Development Strategies in SemiIndustrialized Economies, New York: Johns Hopkins University Press

Bank for International Settlements (1998) 68th Annual Report

Carroll, L. (1872) Alice Through the Looking Glass, Oxford: Oxford University Press

Chang, H. (1998) 'Korea: the misunderstood crisis', World Development, Vol. 29, No. 8

Dataquest (1998) 'The impact of the Asian financial crisis on worldwide electronics production and the semiconductor market', SCND-WW-DP9801

Ernst, D. (1997) 'Technology management in the Korean electronics industry: what factors explain the dynamics of change', paper presented to Conference on Business Systems in the South, Department of Intercultural Communication and Management, Copenhagen Business School, January 22-24

Freeman, C. (1998) 'The East Asian crisis, technical change and the world economy', Review of International Political Economy, 5:3, Autumn, pp. 393-409

Griffith-Jones, S. (1996a) 'How can future currency crises be prevented or better managed?' in J. Joost Teunissen (ed.), Avoiding Mexico-style Crises. FONDAD, The Hague

Griffith-Jones, S. (1998) Global Capital Flows: Should They Be Regulated? Macmillan Press

Haq, M. ul; I. Kaul, and I. Grunberg (1996) The Tobin Tax: Coping with Financial Volatility, New York : Oxford University Press

Harberger, A.C. (1986) 'Applications of Real Exchange Rate Analysis', mimeo, University of California Los Angeles, and University of Chicago

Helleiner, G.K. (ed.) (1994) Trade Policy and Industrialisation in Turbulent Times, London: Routledge

Icahn, C. (1993) 'The importance of manufacturing in a robust economy', RSA Journal, June, pp. 440-49
Inter-American Development Bank (1990) Economic and Social Progress in Latin America, Washington: IADB

Kaplinsky, R. (1993) 'Export processing zones in the Dominican Republic: transforming manufactures into commodities', World Development, Vol. 22, No. 3: 1851-1865

Kaplinsky, R. (1998a) 'Globalisation, industrialisation and sustainable growth: the pursuit of the nth rent', Discussion Paper 365, Brighton: Institute of Development Studies, University of Sussex

Kaplinsky, R. (1998b) 'If you want to get somewhere else, you must run at least twice as fast as that!': the roots of the East Asian crisis', paper presented to East Asia Workshop, 13-14 July, Brighton: Institute of Development Studies, University of Sussex,

http://www.ids.ac.uk/ids/research/kaplin.pdf

Maizels, A., K. Berge, T. Crowe and T. B. Palaskas (1998) 'Trends in the manufactures terms of trade of developing countries', mimeo, Oxford: Finance and Trade Policy Centre, Queen Elizabeth House

Radelet, S. and J. Sachs (1998) 'The onset of the East Asian financial crisis', mimeo, Boston: Harvard Institute for International Development

Reich, R.B. (1991) The Work of Nations: Preparing Ourselves for 21st Century Capitalism, New York: Simon and Schuster

Schumpeter, J.A. (1961) The Theory of Economic Development, Cambridge, Mass: Harvard University Press

Wade, R. (1998) "Asian water torture": personal view', Financial Times, 23 June

Wood, A. (1991) 'Global trends in real exchange rates 1960-84', World Development, Vol. 19, No. 4 , pp. 317-32

Wood, A. (1994) North-South Trade, Employment and Inequality: Changing Fortunes in a SkillDriven World, Oxford: Clarendon Press

Wood, A. (1997) 'Openness and wage inequality in developing countries: the Latin American challenge to East Asian conventional wisdom', World Bank Economic Review, Vol. 11, No 1: 33-57

World Trade Organisation (1995) International Trade: Trends and Statistics, Geneva 